\title{
РЕЦЕНЗІЯ \\ НА «ЗАПИСКИ НАУКОВОГО ТОВАРИСТВА IМ. ШЕВЧЕНКА В АМЕРИЦІ» \\ (Нова серія. Том 1. Головний редактор серії Григорій Грабович; редактор тому Олесь Федорук. Нью-Йорк, 2017, 256 с.)
}

REVIEW

OF «NOTES OF THE SCIENTIFIC SOCIETY NAMED BY SHEVCHENKO IN AMERICA».

(New series. Volume 1. Editor-in-Chief of the series Hr. Hrabovych; editor of the volume O. Fedoruk. New York, 2017, 256p.)

Представлені у першому томі Нової серії Записок Наукового товариства ім. Шевченка в Америці наукові статті і розвідки, присвячені творчості Тараса Шевченка і Пантелеймона Куліша, спонукатимуть до діалогу із авторами не лише літературознавців чи лінгвістів, а й психологів і філософів. Цінний здобуток двомовного (українськоанглійського) видання - долання рамок філологічних наук і орієнтація на горизонт україністики і ширше - сучасної гуманітаристики. На особливу увагу заслуговує те, що автори більшості публікацій активно випробовують можливості різноманітних методологій для осмислення текстів, контекстів та інтертекстів.

Наукове видання «Записки НТШ - А. Нова серія» (Нью-Йорк, 2017) є по суті продовженням «Записок НТШ» (виходили у Львові з кінця 19 століття до 1939) та «Записок НТШ-А» (виходили в США 31953 до 2001). Це видання слід 
означити як знакове явище української культури і науки 20 століття, а його історія тісно переплетена із історією України. Більше сотні томів вийшло на початку минулого століття з 1897 по 1913 роки, із перервами «Записки» виходили у міжвоєнні часи, причому публікація їх припинилася 1939го, коли радянська влада закрила Наукове товариство імені Тараса Шевченка. За рік по відновленню його на еміграції 1948 у Мюнхені було опубліковано 156 том Записок. Створене 1947-го в Америці НТШ-А почало видавати Записки, і впродовж сорока років випустило 50 томів.

У передмові до першого тому Нової серії головний редактор видання, тодішній Президент НТШ-А, знаний літературознавець і професор кафедри української літератури Українського наукового інституту Гарвардського університету Григорій Грабович запропонував короткий огляд історії «Записок», зазначивши, що у 1970-1980-х роках центр тяжіння україністики змістився до західної україністичної науки, зосередженої навколо університетів США і Канади (Гарвардського університету та його Українського наукового інституту в США і Канадського інституту українських студій при Альбертському університеті та кафедри україністики при Торонтському університеті в Канаді). Нова сторінка в житті видання почалася із відновленням НТШ у Львові і здобуттям Україною незалежності. На межі 1989-1990-го стартувала й історія поступового «передавання» Записок до України. Періодичність виходу наступних чисел - окрема складна історія для прискіпливих істориків української наукової періодики. За словами Григорія Грабовича попри те, що протягом 1990-2009 наукова продукція НТШ-А меншала, з 2009 помітна активізація роботи 3 підготовки і друку серії видань, зосереджених навколо постаті Тараса Шевченка та доробку його 
сучасників, зокрема, Пантелеймона Куліша. Поступово викристалізувалася й ідея того, що для повноцінної наукової комунікації і дискусії таки потрібен науковий журнал (українсько-англійський) із фокусом на питаннях українознавства. Таким виданням за словами Григорія Грабовича i мають стати «Записки НТШ-А. Нова серія» - із орієнтацією на забезпечення актуальності, динамізму і високої якості українознавчих дисциплін.

Перший том нової серії Записок присвячено переважно Патронові Товариства Тарасові Шевченку, але є в ньому і матеріали про творчість Пантелеймона Куліша, і розвідки про Шевченкове оточення, і спроби реконструкції контексту української і європейської літератури 19 століття. Наукові пропозиції кількох поколінь українських науковців, представлених у виданні, засвідчують його спрямування на увиразнення широкої тематики і проблематики. На високу оцінку заслуговує і його виважена структура, що складається з кількох рубрик («Статті», «Матеріали», «Рецензії», «Хроніка» тощо).

Найбільшим розділом є «Статті», в ньому представлено сім праць, більшість із яких присвячено осмисленню творчості Тараса Шевченка - у текстуальному та інтертекстуальному вимірі. Том відкривається статтею Ніни Чамати «Українське поетичне послання першої половини 19 століття : генеза і типологія», в якій досліднищя зосереджує увагу на особливостях зразків означеного жанру у Петра Гулака-Артемовського, Степана Писаревського, Віктора Забіли та детально розглядає специфіку подібних творів у Тараса Шевченка.

Григорій Грабович і Тамара Гундорова пропонують нові концептуальні підходи до сучасного аналізу засад творчості Тараса Шевченка на основі використання можли- 
востей міждисциплінарних методологій. Обидві статті відомих літературознавців виходять за межі філологічних інтерпретацій і є двома авторськими версіями вступу до філософії поета. Так Григорій Грабович («Shevchenko's Archetypes») презентує не лише осмислення колективних та індивідуальних архетипів у найвідоміших творах Тараса Шевченка, використовуючи потенціал ідей Карла-Густава Юнга, але й виходить на осягнення співвідношення міфу та архетипу, окреслює специфіку індивідуалізації і самоідентифікації поета та перспективу розгляду мета-архетипу. Тамара Гундорова («Цивілізаційні проєкти Тараса Шевченка : Кобзар Дармограй, фемінізм і хуторянство») зосереджує увагу на цивілізаційних проєктах Тараса Шевченка на прикладі розгляду його російськомовної прози. Повісті Шевченка цікавлять дослідницю скоріше не як джерело пізнання автобіографії митця, а як джерело пізнання «моделей суспільного та морального перетворення, які той освоює». У центрі ії уваги - цивілізаційний проект, який постає у повістях і закладає основи української хутірської культури. Передусім вона осмислює статус оповідача Кобзаря Дармограя (псевдонім Тараса Шевченка) і притаманного йому способу сповідування. Методологія, заснована на феміністичній критиці та елементах психоаналізу, дозволяє дослідниці помітити в повістях низку смислотворчих моментів і кодів, які були прикметні для культурних, суспільних і освітніх трансформацій 19 століття у світі. До діалогу із Тамарою Гундоровою спонукає і порівняння версій хутірської культури у Тараса Шевченка і Пантелеймона Куліша.

Редактор тому Олесь Федорук представляє наукове дослідження про автоцензуру в романі Пантелеймона Куліша «Чорна Рада» і розвідку «Улюблені пісні Шевченка в 
записах Куліша (Нові матеріали)». Детальний аналіз української і російської версій «Чорної Ради» й епістолярію автора твору виводить дослідника на низку важливих спостережень за специфікою автоцензури як явища і особивостей ії прояву. Олесь Федорук пропонує розглядати усі тексти роману - його редакції і різномовні версії - як єдиний «метатекст», що вібрує в полі авторської уяви. У джерелознавчій розвідці «Улюблені пісні Шевченка в записах Куліша (Нові матеріали)», натомість, він представляє дослідження, що стосується перебування Тараса Шевченка в Мотронівці у січні 1847, де його Куліш запросив на своє весілля старшим боярином. Цей епізод, засвідчений в спогадах та листах і самого поета, й осіб його оточення, дає початок «археологічним» пошукам Олеся Федорука по кількох архівах. У результаті дослідник не просто осмислює значення записаних Пантелеймоном Кулішем улюблених пісень Шевченка, а намагається реконструювати контекст появи цих записів. Розвідка доповнюється ілюстративним матеріалом (автографами) і новим видруком текстів пісень.

Пошуки контекстів для осмислення відомих творів Шевченка характерні і для публікацій Олександра Бороня і Василя Задорожного. Статтю Олександра Бороня «Твори німецької літератури в інтертексті Шевченкових повістей» присвячено аналізу європейського контексту сенсів повістей Шевченка. Автор звертає увагу на те, що поклики на Фрідріха Шиллера, Иоганна Вольфганга фон Гете, Кристіана Августа Вульпіуса, Августа Коцебу у творах українського письменника. Василь Задорожний у статті «До інтерпретації Шевченкової поеми «Гайдамаки» зосереджується на двох репліках героїв і представляє широкий горизонт їх тлумачень на основі семантичного аналізу, майже мікро- 
скопічного прочитання фраз і пошуку контекстів, в яких вони могли з' явитися.

Для Романа Трифонова і Ганни Яновської («Мовні засоби самоіронії в листах Шевченка») вихідною є теза про своєрідність стилістики і прагматики епістолярію Тараса Шевченка, що виводить їх на необхідність відмовитися від думки про брак самоіронії у поета. Саме аналіз проявів і парадоксальності самоіронії дозволяє дослідникам деконструювати усталений образ Тараса Шевченка і презентувати його як митця і особистість 3 несподіваної перспективи. Міждисциплінарний підхід Романа Трифонова і Ганни Яновської до епістолярію базується на поєднанні лінгвістичної і психологічної методології із незначною часткою спрямувань культурної критики, хоча психолінгвістичний аспект у їх дослідженні і домінує. Розглядаючи функції і самоіронії та іï засоби, дослідники поступово окреслюють кілька напрямків трансформацій підходів до епістолярного дискурсу Шевченка та загалом до епістолярію українських літераторів.

У «Записках НТШ-А» вмішено і посмертні публікації двох відомих українських дослідників Володимира Яцюка (1946-2012) і Віктора Дудка (1959-2015). Обидві джерелознавчі розвідки містять цінні матеріали, котрі відкривають невідомі сторінки життя і самого митця, і його оточення. У центрі розвідки Віктора Дудка «Із нових розшуків про Шевченка» опиняються віршоване послання Ніколая Курочкіна до Шевченка та декілька інших документів, 3 яких постають важливі нюанси, необхідні для реконструкції і біографії митця, і кола його спілкування, і окремих спрямувань у його творчості. У статті Володимира Яцюка «Раритетні збірки Плацендара: спроба атрибуції» презентовано і майстерно прокоментовано раритетні фотогра- 
фічні портрети Тараса Шевченка і його сучасників. Остання праця відомого дослідника і колекціонера, проілюстрована відповідними світлинами, містить багато цінної інформації як про різні роки життя і контакти поета, але й авторський аналіз фотографій і візуальних образів Миколи Костомарова, Михайла Лазаревського, Григорія Честахівського, Марусі Денисенко. До слова, опублікована у «Записках» праця Володимира Яцюка є частиною монографії «Тараса Шевченко і світ фотографії», яка нещодавно з'явилася у видавництві «Критика».

Варто відзначити конщептуальну і змістовну цілісність першого тому нової серії «Записок НТШ-А». Більшість статей у виданні відрізняються зорієнтованістю на чітку методологічну позицію і детальний аналіз розглядуваних текстів у поєднанні із ненав'язливою, але послідовною і поміркованою реконструкцією контекстів. Чеснотою представлених праць є відкритість до дискусій і прагнення уникати безгрунтовних узагальнень. Центральну частина видання, представлену рубриками «Статті» $\mathrm{i}$ «Матеріали», вдало доповнює «Miscellanea», де вміщено окрім згаданої розвідки Віктора Дудка ще й дослідницькі нотатки Юхима Меламеда «Із коментаря до «Шевченкового словника» із цінною інформацією про Тетяну Волховську, Фелікса Волховського, Тадеуша Чацького. Позитивне враження від цілісності видання підтримують і вміщені у відповідних рубриках рецензія Роксани Харчук на друге видання монографії Станіслава Росовецького «Шевченко і фольклор» (Київ: Критика, 2015), некролог Віктору Дудкові та хроніка наукових конференцій, круглих столів, літературних і музичних вечорів й інших форм діяльності українознавчих осередків України й діаспори. 
Українське релігієзнавство № 94

Попри позірну філологічну зорієнтованість, перший том Нової серії «Записок НТШ-А» представляє різноманітні орієнтації української гуманітаристики - передусім завдяки актуальним контекстам, які актуалізуються в переважній більшості статей та діалогічним перегукам і концептуальним зв'язкам між дослідницькими спрямуваннями в окремих публікаціях.

Юлія Доброносова кандидатка філософських наук оглядачка, письменниця 